\title{
Have You Ever Seen the Void? Interest Groups Concerns Toward the Weakening Representational Role of Political Parties in European Countries
}

\author{
Chiara Fiorelli
}

\section{Abstract}

Contemporary democracies face a trend toward the diffusion of the representational void left by under- legitimized political parties (Mair 2013). The essential functions of traditional political parties to organize and articulate political conflict and societal interests have been challenged both from the inside of the party system, by the emergence of populist habits of newcomers, and from the outside, by the progressive erosion of old political culture and corresponding increasing of hostility feeling. Intermediaries organizations of political and economic interests usually push their demands toward political actors in order to shape policy choices. What can happen when the traditional party system suffers from de- legitimation? In this paper, I will try to understand the level of concern of interest organizations toward the progressive detachment of civil society from political actors, in order to define if the risk of a void of representation is perceived as real and contingent. Thanks to a new original European dataset (the Comparative Interest Groups Survey), the analysis shows that different types of interest groups perceive the void to be real and with a possible impact on their activities and their own survival. As expected, in the regression model, differences emerge between countries with a traditional strong interests' system and countries where groups activities are usually barely regulated. The results support the idea that the distance between civil society and political representatives should be considered a prominent focus of contemporary social and political investigation in order to understand the challenge for democratic life and the possible strategy of reaction.

Keywords: representation, intermediation, interest groups, comparative perspective

\section{Introduction}

Contemporary democracies face various challenges that are threatening its representative basis. Among European countries, the trust in institutions, politicians and political parties is decreasing, along with their legitimation. 
Peter Mair (2013) emphasizes the risk related to the void of representation left by the decreasing role of political parties as traditional intermediaries of civil society instances that could lead toward a change in the type of democracies western countries are used to know, not representative any longer.

The threat to democracy comes from both side of the society: on one hand, politicians, and so governments, seem to be less and less accountable for their choices because they are subject to

pressures and instances coming from a multilevel political scenario and they are also enlarging the gap between them and the citizens; on the other hand, the civil society seems to be more and more critical to the political process and also increasingly disaffected from the traditional ways in which politics, and so representation, is organized -through parties, delegation, etc. (Mair 2013).

In contemporary scenario, the void left by the disaffection and the lack of general representation can become desirable to many other actors, international or national ones, with the risk that specific interests overtake the position of collective interests in the ordinary political work, leading to a more micro-policy oriented governments responsive to specific interests.

If we move our attention toward politicians and governments, the challenge to partygovernment and the progressive establishment of parties as agents of the state rather than civil society' representatives has led to a decline of partisanship in policy-making and in governmental activities (Mair 2008), due in part to the concurrent decline of collective identities within western electorates. This process undermines the accountability of governments and politicians and creates the opportunity for non-majoritarian institutions to rule or take advantage of this situation (Majone 1996). Non-majoritarian agencies (es. NGOs or sectorial associations) are consider to be less accountable for their choices and their behaviour in contrast to political parties and politicians that are usually evaluated by their electorate.

Overall, the traditional political collective actors represented by political parties are losing their role as intermediaries that channel societal demands. This declining trend raises fundamental questions in democratic systems concerning the way political conflict should be managed when traditional intermediaries do not reflect the current environment.

In this scenario it is fundamental to ask whether or not interests groups react to, and perceive, the growing distance between politicians and citizens. In order to understand the strategies and the representative role of organized interests, this paper aim to define if intermediaries' associations are defining themselves as alternative to political parties (Dalton 2002). 
Therefore, the underlined hypothesis of this paper will be that the coexistence of disaffection from traditional politics by both citizens and politicians create a void in the political arena that increase the perceived relevance of specific interest groups in a society as political intermediaries.

Analysis are based on the data coming from the Comparative Interest Group Survey ${ }^{1}$ considering the organization level as unit of investigation.

\section{Literature review}

Two basic assumptions apply to democratic societies: first, that elected politicians should pursue the public interest, and second, that citizens should be guaranteed inclusive participation (Melchionda 1997). On the one hand, inclusion and the right of opposition are the main defining features of the level of democratisation (Dahl 1971). On the other hand, modern democracy is largely based on two factors: representation, understood as meaning 'acting in the interest of the represented, in a manner responsive to them' (Pitkin 1967: 209), and the existence of repeated, transparent elections to guarantee the legitimacy of the elected representatives. In this scenario, political parties, as collective actors, play a fundamental role representing the civil society cleavages by competing with each other in democratic elections (see Dahl 1971, Schattschneider 1942, Lipset and Rokkan 1967).

The main focus of this kind of debate is related to the role of representation, both political and societal one. The most basic definition of representation is based on the resemblance between representatives and represented. Sartori (1987) points out that the concept is multidimensional: it embraces political, sociological and legal aspects. As Urbinati and Warren (2008) indicate, parliaments are the primary loci of representation but the word can be understood as a principal- agent relationship (Pitkin 1967); or as a space within which the sovereignty of the people is identified with the state power (electoral representation); or can indicate the mechanism that ensure some measure of responsiveness; or can recall the value of political equality thanks to the universal franchise. In this scenario, "political parties are the key representative bodies within representative governments. Their representative functions include aggregating and deliberating interests and values, linking issues through programmatic visions in an increasingly segmented political environment" (Urbinati and Warren 2008:400).

The hollowing of traditional cleavages, and the way citizens behave into the political arena, as well as the way they look for representation, has defined new interactions between the civil society and

\footnotetext{
1 Beyers, J., Bernhagen, P., Borang, F., Braun, C., Fink-Hafner, D., Heylen, F., Maloney, W., Naurin, D., Pakull, D. (2016) Comparative Interest Group Survey Questionnaire (Edition: January 2016). University of Antwerp.
} 
the parties as intermediary actors of their interests. However, it is widespread among scholars the opinion and evidence that the role of party is declining, or better changing, in advanced societies. As Ignazi (1996) noted, the party decline concerns a certain type of party: the mass party. Mass parties failed to meet the demands of a new western publics in articulating and in aggregating interests (Lawson, 1980).

However, if political parties can be considered the most privileged actors in a political system, for their direct access to the public decision-making process through the electoral legitimation of citizens, they are not the only ones that represent and articulate demands toward the political system. Civil associations and organized interest groups are usually created and arranged for this purpose, helping the system to articulate the specific demands of their main concern.

It is evident that in western democracy, representation is changing for parties but not for interest groups. Parties are considered to be less and less responsible for the collective will, while the aim of organized interests does not change: they are accountable for a specific representation, the one of their small, narrow and particular constituency

Societies are drastically changing, and are facing challenges that undermine the traditional actors in political competition. Political parties are in decline, with party membership decreasing rapidly almost everywhere in established democracies (Mair and Van Biezen 2001, Scarrow 2002). Increasingly few citizens choose to identify themselves and their interests with these parties (Dalton 2002), and the overall trust in political parties and their political skills has considerably decreased (Pharr, Putnam, and Dalton, 2000).

Nonetheless, political parties remain the most powerful political actors, with their direct access to public office. Despite evidence of their decline (see Ignazi 2014), they play an important connecting role between the state and the citizens (see Bartle and Bellucci 2009).

As Mattina (2011) stands, interest groups can answer to the demand of society for organization, expertise, resources and legitimation. For many scholars, groups provide a mechanism through which citizens who have a shared attitude or a shared interest can come together and transform their collective resources into political action (Thomas, 2001). For this reason, the interest group, as a secondary association, contributes to the political intermediation (Van Deth, 1997; Gunther et al., 2007). As Bellucci et al. (2007) pointed out, in political commitment, unions and professional associations are far more effective in acting as political intermediates. Secondary associations based

on traditional cleavages still have higher capacities to encapsulate segments of the electorate than any other civic groups. In the political system, social cleavages are 
usually articulated through and with the help of intermediary organizations (Easton, 1965).

As Aarts (1995) shows, the increase in material wealth has made material inequalities less important and the rise of new mass media has challenged the role of social organizations. However, even if the political linkages have declined as consequence of long-term developments, there is non evidence for a general decline in individual linkages to intermediary system. The risk is straightforward, if political parties detached themselves from civil society, whilst individuals are still engaged in associations, in the long run the legitimation of the system can be at compromised (Aarts 1995).

To be representative, an interest group should be embedded in a political system as an external intermediary actor supported by the legitimation of its identity in the environment. The access of organized interests to the political system is subject to the social reputation of the group; its membership; and the presence of authoritative representatives, expertise and systemic factors, such as institutional constraints, traditions of policy making and political system features (Morlino, 1998). These factors contribute to shaping the basic distinction between insider and outsider groups: the former are those groups recognized as political interlocutors by the political system; the latter usually act outside the institutions and through indirect lobbying (Grant, 2005).

Looking at the more general perspectives, research in this field has usually followed three different approaches: the corporatist, the pluralist and the elitist (Yishai, 1991). In the U.S. literature, the pluralist and neo-pluralist approaches have attracted a lot of attention since the beginning of group studies (see Bentley, 1908; Truman, 1951). This school argues that no particular interest groups dominate in specific policy arenas but, rather, there is a plurality of actors competing or co- operating with each other (see Berry, 1984; Bosso, 1987). This perspective was in contrast with the elitist one that believed that special interests were dominating in specific policy arenas (Olson, 1965; Lowi, 1969).

On the contrary, European scholars were much more attracted by the corporatist and the neo- corporatist perspectives, due to the rise of social pacts among European countries in the 1970s (see Lehmbruch and Schmitter, 1982; Crouch, 1993). According to Wessels (1996), organized business tends to be more powerful in countries with a corporatist tradition, such as Northern Europe countries, Germany, Austria and Netherlands. In Italy the organized business sector looks differentiated and with low pressure power. In addition, it has been described a trend, in the Italian interest system, toward fragmentation and differentiation (Lizzi and Pritoni 2017). The same pattern is recognizable for trade unions, which are powerful in corporatist countries and highly fragmented elsewhere, as in Italy, France and Spain. For the new democratic countries, such as the former URSS or the former 
Yugoslavia countries, some elements of corporatism persist in the pluralist environment of democratic transition (Luksic 2003, Hrebenar et al. 2008).

Despite the dominant theoretical perspective adopted in the past, interest group studies seem now to converge (Mahoney and Baumgartner, 2008). European scholars were usually deeply rooted in policy system dynamics, while U.S. scholars were more concerned about lobbying activities. Currently, both seem to focus on the impact of government structures on the development of national interest systems. However, the aforementioned studies considered political parties and interest groups as two autonomous actors, focusing on one side or another, or considered them as alternative intermediates (Dalton 2002), emphasizing their functional differences (Bayers et al., 2008) or their connection with governing parties.

\section{Hypothesis and Data}

The current literature has not taken under investigation the role that interest groups may absolve in contemporary democracies facing the progressive de-legitimation of traditional political actors, such as political parties. This paper wants to fill this gap by providing a first empirical attempt to analyse the perception of organized interest toward the weakening of trust in political actors.

Usually, the limit regarding the availability of data and the sectorial focus on interest groups strategies have been an obstacle toward a more systematic analysis on the relationship between groups and political parties, as well as toward a deeper understanding of groups' evaluation of the progressive de-legitimation of politicians.

The main hypothesis of this work is that those organized interests and interest associations do not consider the progressive detachment of citizens from their political representatives to be a relevant issue.

This hypothesis is based on the idea that stronger organized groups - those with membership-based participation, and those with a stronger organizational structure (thus unions and business groups)- already perceived themselves as political intermediaries, or political alternative, to political parties.

The void of representation between citizens and political parties can thus perceived as a real threat to democratic process only among those groups that present a dependence on political parties' intermediation and where the access to the policymaking process necessarily involve the intermediation of political actors.

Analysis are based on the Comparative Interest Group Survey. The project involves 9 European countries (Belgium, Netherlands, Czech-Republic, Italy, Lithuania, Poland, Slovenia, Spain, and Sweden). Up to now, data are available for 6 countries. The aim of the project is to collect and to provide data on interest organization and to map the strategies and the role of interest groups in Europe. Most of survey were collected between 2015 and the end of 2017 . 


\section{Analysis and Results}

The Comparative Interest Group Survey offers an opportunity to investigate the perspective of interest groups in different European countries over strategical and organizational features.

As far as the aim of this paper is to provide evidence that interest organization recognize the weakening of traditional political actors and perceive it as either an opportunity to cover the void of representation left by the progressive distance of citizens from politicians or as a threat to their own subsistence, it is fundamental to take under consideration the characteristics that can shape this perception.

The analysis that follow should be considered as explorative of a new perspective on the relation, and re-action, between interest groups and traditional political actors.

First of all, Table 1 shows the composition of the sample taken under investigation. The organizations that answered the survey were 4650 for the 6 countries considered: Belgium, the Netherlands, Italy, Slovenia Lithuania and Sweden. Most of the organizations are related to Institutional and Public interests, followed by Business and Occupational groups. The categories of interest less represented in the sample are Unions and Religious ones. The former are usually bigger groups with less internal fragmentation and the latter, although strongly present, depend on the cultural and traditional arrangements in society.

Institutional and Public groups are strongly represented in Sweden and the Netherlands, Occupational groups emerge as predominant category Lithuania and Slovenia, while economic groups -Unions and Business- are particularly relevant in the Italian sample.

Tab.1 - Sample Distribution on Type of Organization and Country (\%)

\begin{tabular}{|c|c|c|c|c|c|c|c|}
\hline & $\mathrm{NE}$ & $\mathrm{BE}$ & IT & LI & SL & SW & $N$. \\
\hline Unions & 1.4 & 2.0 & 16.5 & 5.6 & 7.7 & 2.8 & 207 \\
\hline Business & 16.0 & 22.6 & 28.2 & 22.3 & 9.3 & 19.0 & 906 \\
\hline Institu./Publ. & 30.1 & 23.3 & 23.0 & 14.5 & 10.3 & 49.4 & 1455 \\
\hline Occupational & 17.0 & 23.4 & 12.3 & 35.2 & 36.0 & 14.0 & 932 \\
\hline Identity & 11.8 & 7.5 & 13.8 & 7.5 & 7.1 & 2.9 & 344 \\
\hline Leisure & 13.3 & 14.3 & 2.9 & 7.8 & 22.3 & 9.1 & 533 \\
\hline Religious & 10.4 & 7.0 & 3.1 & 7.0 & 7.3 & 2.8 & 273 \\
\hline$N$. & 874 & 959 & 478 & 358 & 439 & 1542 & 4650 \\
\hline
\end{tabular}

Source: Comparative Interest Group Survey (www.cigsurvey.eu). Author's elaboration

There is a difference in representation dynamics of an interest group between potential and actual representation. The first one represents the complete set of individuals that are sharing a particular interest or demand for a specific political intervention on the basis of a common status/economic/cultural/spiritual goal; on the other hand, the actual representation is the effective number of 
citizens/worker/companies that are members of a specific association. In the sample considered, Business, Institutional and Occupational association declared, on average, to represent more than $50 \%$ of their potential members, while Unions, Identity groups and Religious associations are above the half of their possibility ${ }^{1}$.

In addition, the role of members for the various activities pursued by the associations varies among countries. Members are considered to be important for different activities in Lithuania, Slovenia, Italy and Sweden, while in the Netherlands and Belgium members received, on average on the various activities, less attention. ${ }^{2}$

If we want to see if and how interest organizations are acting as representational actors in a political system, the strategy of action they pursue should be evaluated trough their main activity chosen. Table 2 reports the share of organizations in each country that declared to have among the main purpose the one of representation, mobilization or media campaigns. All those activities may favour a partisan recognition of the organization by not only their specific members. ${ }^{3}$

Tab.2 - Interest Organizations involved in activities (\%)

\begin{tabular}{l|lll} 
& Representation & Mobilization & Media Campaigns \\
\hline IT & 75.6 & 60 & 69.7 \\
BE & 64.5 & 52.2 & 29.8 \\
LI & 82.9 & 63.5 & 27.8 \\
NE & 61.6 & 32.4 & 27.3 \\
SL & 41.8 & 50.6 & 29.8 \\
SW & 72.9 & 45.7 & 40.9 \\
\hline Overall & 65.9 & 48.3 & 35.9 \\
N. & 2424 & 1774 & 1315
\end{tabular}

Source: Comparative Interest Group Survey (www.cigsurvey.eu). Author's elaboration

In Italy, interest organizations responding the survey seem to cover all the activities that have a potential influence on the citizens. In Belgium, the Netherlands and in Lithuania most of the organizations prefers to focus on representational and mobilizing activities. Slovenian organizations focus on mobilization while in Sweden there is a preference toward representational activities. The case of Italy should be noted: it is the only country where the media campaigns are declared as an important activity for over the $60 \%$ of the associations interviewed.

\footnotetext{
1 The original question was: "What percentage of potential members are actually members of your organization?"

2 The question asks: "How important are members to your organization with regard to the following activities?" regarding 6 different activities such as generating income for the organization, providing idea or helping to influence public policy (scale from $1=$ Not at all important to $5=$ Very important).

3 Business groups and the Netherlands as reference category.
} 
Table 3 shows the average share of time that organisations spend between direct strategies, such as contacts with politicians and civil servants and indirect strategies, such as media coordinating, letter writing, e-mailing or social media campaigns, rallies and demonstrations.

Business organizations seem to be more involved in Direct strategies, followed by Unions, Institutional groups and Occupational (all the groups demanding for specific policy aims). Differences among countries emerge: organizations in Italy, Sweden and Lithuania are more involved in Direct strategies of action, while in Belgium, the Netherlands and Slovenia, on average, associations declared to prefer to act through indirect pressure.

Tab. 3 - Percentage of time spent by Interest Organizations in Direct or Indirect strategies (\%)

\begin{tabular}{l|lll|ll}
\multicolumn{2}{c}{ Direct Strategy } & $\begin{array}{l}\text { Indirect } \\
\text { Strategy }\end{array}$ & \multicolumn{2}{c}{ Direct Strategy } & $\begin{array}{l}\text { Indirect } \\
\text { Strategy }\end{array}$ \\
\hline Unions & 46.13 & 49.53 & IT & 48.35 & 47.93 \\
Business & 49.48 & 46.27 & BE & 39.56 & 50.63 \\
Institu./Publ. & 46.56 & 48.76 & LI & 41.86 & 59.27 \\
Occupational & 40.04 & 52.18 & NE & 39.94 & 48.42 \\
Identity & 38.17 & 52.83 & SL & 31.68 & 50.35 \\
Leisure & 35.63 & 51.34 & SW & 45.67 & 53.75 \\
Religious & 34.07 & 58.30 & TO & 41.63 & 51.59 \\
\hline
\end{tabular}

Source: Comparative Interest Group Survey (www.cigsurvey.eu). Author's elaboration

After the report of the activities of organizations and the role they recognize to their members in shaping their strategies, it is important to see how interest groups perceived the growing distance between citizens and politicians as a challenge for their own survival. The distance between citizens and politicians can be understood as proxy of the void of representation of political actors, as far as the latter are consider to be less and less responsive to the requests of the former and this dynamic may create a representational space to be fulfilled.

Table 4 reports the percentage of organization identifying the growing void as a challenge that they have to face ${ }^{1}$. Most of the organization seem not to consider the distrust over politicians important, while only $12.6 \%$ of the associations recognize it as a very important issue to be considered.

Among countries, in Slovenia and Lithuania organizations are distributed along the all points of the scale, in Belgium and, especially, in the Netherlands interest

\footnotetext{
1 The original question asks: "How important are the following political challenges for your organization? The distance between individual citizens and policymakers (" in a 5 points scale from $11=$ not at all) to 5 (=very important). In Sweden the question was not on the questionnaire.
} 
organizations tend to not consider it as an important challenge to face, while in Italy the most of the respondents are well concerned about the space that divides citizens and their political representatives. Ove all the countries, $62 \%$ of Unions organizations consider this topic to be a very important challenge to face, followed by Public

groups and Religious associations (39\% and 35\%), while only the $20 \%$ of Business groups declared to have the same perception.

Tab.4 - Perceived importance of the distance between citizens and policymakers as a challenge ( $\%$ of organizations)

\begin{tabular}{l|lllll|l} 
& $\begin{array}{l}\text { Not at all } \\
\text { imp }\end{array}$ & $\begin{array}{l}\text { Not very } \\
\text { imp }\end{array}$ & $\begin{array}{l}\text { Neither imp } \\
\text { nor unimp }\end{array}$ & Important & $\begin{array}{l}\text { Very } \\
\text { important }\end{array}$ & N. \\
\cline { 2 - 8 } IT & 12.7 & 9.6 & 12.4 & 34.5 & 30.7 & 394 \\
BE & 39.3 & 16 & 19.4 & 17.1 & 8.1 & 725 \\
LI & 20 & 9.1 & 23.7 & 26 & 21.1 & 350 \\
NE & 75.4 & 8.5 & 8.7 & 5.9 & 1.6 & 698 \\
SL & 28 & 13 & 16.8 & 27.4 & 14.7 & 368 \\
\cline { 2 - 7 } TOT. & 40.8 & 11.6 & 15.6 & 19.4 & 12.6 & 2535
\end{tabular}

Chi-squared: $737.633(0.000)$

Source: Comparative Interest Group Survey (www.cigsurvey.eu). Author's elaboration

In order to evaluate the impact of the variable consider, Table 5 reports the coefficient of a regression model (OLS with fixed effects) ran on the importance of the distance between citizens and politicians ${ }^{1}$. The variable does not tell us if the distance is perceived as a threat or as an opportunity for the organization but it can help to understand how they consider the detachment of civil society from political representatives to be a challenge (positive or negative) to face, how interest's organization pay attention to the representative void of political actors. Models have been tested for collinearity and residuals distribution.

As the hypothesis wants to see if interest organizations can be considered as alternative representative actors to political parties, I should expect that the role of members, structure of the organization on the country and the presence of others challenging actors may be relevant: more importance of members in shaping the political strategies, more organizational chapters and more challenging actors should rise the importance of the question of void. In addition, the type of interest covered by the organization should also affect the perception of void: economic and institutional groups should pay more attention to the growing distrust toward

${ }^{1}$ For the list of variables included see the Appendix. 
politicians because they are usually more involved in direct relations with political actors.

Tab.5 - Regression model (OLS -f.e.) on perceived importance of the distance between citizens and policymakers 6

Members on Pol. Strategies Mod.1 Mod.2 Mod.3

s.e.

$0.201 \quad 0.214 \quad 0.13$

Threat by others

$\begin{array}{lll}0.043 & 0.031 & 0.03\end{array}$

s.e.

0.472

0.317

0.327

Local Chapters

0.024

0.027

0.025

s.e.

0.484

0.373

0.121

Unions

0.062

0.062

0.061

s.e.

0.497

0.247

Institu./Public

0.132

0.122

s.e.

0.37

0.361

Occupational

0.09

0.082

s.e.

$0.085^{*}$

$0.104 *$

Leisure

0.083

0.077

s.e.

$-0.262$

$-0.208$

Religious

0.108

0.101

s.e. $0.042^{*}$

$0.208^{*}$

Changes in Public opinion

0.131

0.12

s.e.

0.141

Individualization

0.024

s.e.

0.142

$\mathrm{BE}$

0.023

s.e.

0.685

IT

0.085

s.e.

1.768

SL 0.098

s.e.

1.2

LT

0.103

s.e.

1.217

0.098

$R$-squared

Only variables with $\left(^{*}\right)$ are not significant: $\mathrm{p}>0.05$

0.243

0.296

0.416

Source: Comparative Interest Group Survey (www.cigsurvey.eu). Author's elaboration

Other control variables aim to cover the political and cultural environment organizations face. The rapid changes in public opinion may be a risk for representative actors, as well as the growing individualism that threat the collective and aggregating bodies.

From the descriptive analysis, it is evident that variation between countries cannot be neglected. Country variables are a set of national assessments and historical 
habits. As reminded before, tradition of neo-corporatist actions recognizes and identify a specific, and strong, role to organized interest that usually are directly included in the political system, while a pluralist, or too young, system of interest is often perceived by organization to be less legitimised and stable. As expected, with the "neo-corporatist" Netherlands as reference category the others country show positive coefficient, especially Italy.

\section{Final remarks}

The progressive distance between politicians and citizens has created a void of representation that risk to be fulfilled by non-majoritarian agencies or actors that are not accountable for their choices.

This void of representation can be also considered as an opportunity for those associations that are already acting in the name of their constituencies: those with that are presenting a structural territorial organization, those where the members are considered to determinant for their strategic political choices, those that have specific poly aims.

The aim of this paper was to investigate the perception, and the perceived risk, of void of representation by interest associations in different European countries. The results show that the progressive distance between citizen and policymakers is recognized to be a challenge to face by most of the organizations.

In addition, to be accountable to members increase the perception of void as an important issue to consider. Differences emerge between various type of associations: unions and institutional-public ones are perceiving the void as a clear challenge that should be taken under consideration, while leisure associations, with less direct policy involvement, are not.

The organisation of the interest system at national level, as revealed by the impact of country variable in the model, emphasises the national differences. Where neocorporatist assets of interaction between the political system and the interest groups are traditional - the Netherlands and Belgium- the distance between citizens and politicians is less perceived as a challenge for the organizations, while in countries that

traditionally adopted a pluralist organization of interest system (where access to policy-making is less regulated), such as Italy, the perception increases.

Overall, it is important to stress that organizations that consider their members to be very relevant in determining their strategic political and policy choices are more aware of the risk of void of representation.

Further analysis should start from that point: interest organisations that are already acting as intermediaries of their members and are accountable to members' positions are recognizing the distance between citizens and policymakers as a challenge for their own organization. 
The risk of void should be better analysed and stress in further research in order to understand where democratic government, based on the central role of political parties as intermediaries of social conflict and demands, is going through.

\section{Appendix}

Dependent variable: Perception of Void between citizens and politicians $(1=$ not at all important; $5=$ very important).

\section{Predictors:}

Influence of Members on organization's decisions on political strategies (reversed: $1=$ not at all influential; $5=$ very influential).

Importance of challenges for the maintenance of the organization: Other forms of political participation ( $1=$ not at all important; $5=$ very important $)$.

If the organization has local chapters $(1=y e s, 0=$ no)

\section{Control:}

Type of organization: dummy variables (1=yes): Business as reference

Country: dummy variables (1=yes): the Netherlands as reference.

Importance of challenges for the maintenance of the organization: Changing of public opinion about the issues important to your organization ( $1=$ not at all important; $5=$ very important).

Importance of challenges for the maintenance of the organization: Individualization ( $1=$ not at all important; $5=$ very important $)$

\section{References}

[1] Aart, K., A. Blais, and H. Schmitt, eds. 2011. Political Leaders and Democratic Elections. Oxford: Oxford University Press.

[2] Aarts, K. 1995. Intermediate Organizations and Interest Representation. In Klingeman H.D. and Fuchs D. (eds.) Citizens and the State. Oxford: Oxford University Press.

[3] Bartle, J., and P. Bellucci, eds. 2009. Political Parties and Partisanship: Social Identity and Individual Attitudes. London: Routledge."

[4] Bellucci, P., M. Maraffi, and P. Segatti. 2007. Intermediation Through Secondary associations: the organizational context of electoral Behaviour. In Gunther, R., J.R. Montero, and H-J. Puhle. Democracy, Intermediation and Voting in Four Continents. Oxford: Oxford Universty Press.

[5] Bentley, A. 1908. The Process of Government: a Study of Social Pressures. Chicago: University of Chicago Press.

[6] Berry, J. 1984. The Interest Group Society. Boston: Little, Brown.

[7] Bosso, C. 1987. Pesticides and Politics: the Life Cycle of a Public Issue. Pittsburgh: University of Pittsburgh Press. 
[8] Crouch, C. 1993. Industrial Relations and European State Traditions. Oxford:Oxford University Press. Dahl R. 1971. Poliarchy. New Haven: Yale University Press.

[9] Dalton R.J. 2002. The Decline of party Identification, in Dalton R.J. and Wattenberg M.P. (eds.) Parties Without Partisans: Political Change in Advanced Industrial Democracies. Oxford: Oxford University Press.

[10] Easton, D. 1965. A Framework for Political Analysis. Englewood Cliffs: Prentice-Hall.

[11] Grant, W. 2005. Pressure Politics: A politics of Collective Consumption. Parliamentary Affairs 58(2): 366-379.

[12] Gunther, R., J.R. Montero and H.J. Puhle. 2007. Democracy, Intermediation and Voting in Four Continents. Oxford: Oxford Universty Press.

[13] Ignazi P. 1996. The Crisis of Parties and the Rise of New Political Parties. Party Politics. 2(4): 549-66. Ignazi, P. 2014. Power and the (il)legitimacy of Political Parties. Party Politics 20(2): 160-169

[14] Lawson K. 1980. Political Parties and Linkage, in Lawson K. (ed.), Political Parties and Linkage. A Comparative Perspective. New Haven: Yale University Press.

[15] Lehmbruch, G. and P. Schmitter (eds.) 1982. Patterns of Corporatist PolicyMaking. London: Sage Publication.

[16] Lipset, S.M. and S. Rokkan. 1967. Party systems and voter alignments: crossnational perspectives. Free Press.

[17] Lizzi, R. and A. Pritoni. 2017. The size and shape of the Italian interest system between the 1980s and the present day. Italian Political Science Review. Published online: 30 March 2017.

[18] Lowi, T. 1969. The End of Liberalism: The Second Republic of the United States. New York: W.W. Norton.

[19] Mahoney, C. and F. Baumgartner. 2008. Coverging Perspective on Interest Group Research in Europe and America. West European Politics 31(6): 1253-1273.

[20] Mair P. 2013. Ruling the Void: The Hollowing of Western Democracy. London: Verso.

[21] Mair P. and van Biezen I. 2001. Party Membership in Twenty European Democracies 1980-2000. Party Politics. 7(1): 5-21.

[22] Majone G., 1996. Temporal Consistency and policy Credibility: Why Democracies Need Non-Majoritarian Institutions, European University Institute, Working Paper, no.96/57.

[23] Mattina, L. 2011. Note a margine delle più recenti ricerche sui gruppi. Rivista Italiana di Politiche Pubbliche 6(2): 387-396.

[24] Melchionda, E. 1997. Il Finanziamento della Politica. Roma: Editori Riuniti.

[25] Morlino, L. 1998. Democracy between Consolidation and Crisis: Parties, Groups and Citizens in Southern Europe. Oxford: Oxford University Press. 
[26] Olson, M. 1965. The Logic of Collective Action. Harvard: Harvard University Press.

[27] Pharr S.J., Putnam R.D. and Dalton R.J. 2000. A Quarter Century of Declining Confidence. Journal of Democracy. 11(2): 5-25.

[28] Pitkin H.F. 1967. The Concept of Representation. Berkeley and Los Angeles: University of California Press. Sartori G. 1976. Parties and Party System. A Framework for Analysis. Cambridge: Cambridge University Press.

[29] Scarrow S. 2002. Parties without Members? Party Organization in a Changing Electoral Environment, in Dalton R.J. and Wattenberg M.P. (eds.) Parties Without Partisans: Political Change in Advanced industrial Democracies, Oxford: Oxford University Press.

[30] Schattschneider, E. E. 1942. Party Government. New York: Rinehart.

[31] Thomas, C. (ed.). 2001. Political Parties and Interest Groups. Boulder: Lynne Rienner Publishers. Truman, D.B. 1951. The Governmental Process. New York: Knopf.

[32] Urbinati, N. and Warren, M. 2008. The Concept of Representation in democratic Theory, Annual Review of Political Science, 11: 387-314.

[33] Van Deth, J. 1997. Private Groups and Public Life. New York: Routledge.

[34] Wessels, B. 1996. System of Economic Interest Groups and Socio-Economic Performance. Paper presented at the 1966 Annual Meeting of American Political Science Association, San Francisco.

[35] Yishai, Y. 1991. The Land of Paradoxes: Interest Politics in Israel. Alabny: State University of New York Press. 